\section{Washington}

THE Metropolitan Edison Company has been indicted on eleven counts of criminal misconduct after a three-year investigation by a federal grand jury into the operation of the Three Mile Island power plant; the jury concluded that for months before the accident at the plant in March 1979, the company had been deliberately falsifying the results of safety tests on the crucial water coolant system.

The grand jury's investigation began after a former reactor operator at Three Mile Island, Mr Harold Hartman, alleged that before the accident, Metropolitan Edison falsified results of safety tests to avoid shutting down the reactor in accordance with the safety procedures specified by the Nuclear Regulatory Commission (NRC). The indictment confirms Hartman's allegations and charges Metropolitan Edison with "a pattern of criminal violations" beginning some time in October 1978 and continuing until the day of the accident.

At the heart of the indictments is a charge that Metropolitan Edison deliberately manipulated its water inventory balance tests, commonly known as the leak rate test. Under NRC regulations, the amount of reactor coolant leaking from the Three Mile Island reactor from unidentified sources should never have exceeded a gallon a minute. If it did, the company had either to reduce leakage back to the allowable level within four hours or reduce power and shut the reactor within 36 hours.

The grand jury claims that Metropolitan Edison knew in 1978 that the leak rate test it was using was an inaccurate measure of the amount of coolant in the reactor, but continued to use "a meaningless procedure" to generate results that appeared to establish that leakage was within acceptable limits. In the course of the tests, the company added water and hydrogen to the coolant system in a deliberate attempt to manipulate the results.

Other indictments say the company failed to reduce power when leakage exceeded the allowable rate, that it destroyed records of the test results despite a regulation that they should be retained for at least five years and that it concealed from NRC the fact that the leak rate test being used was not an accurate measure of coolant leaks.

The maximum total fine for all the violations is $\$ 85,000$ and the cost of the prosecution - considerably less damaging to Metropolitan Edison's finances than to its reputation and that of the nuclear industry as a whole. Department of Justice officials refuse to say whether the grand jury believed the company's violations contributed to the 1979 accident, but the indictment is bound to fuel public speculation on those lines. The accident was caused by a failure of the reactor's pressurizing system and the consequent reduction of coolant level in the reactor and overheating of the uranium fuel.

For the General Public Utilities (GPU) Corporation, Metropolitan Edison's parent company and the organization responsible for cleaning up Three Mile Island, the grand jury indictment is merely the latest in a series of unwelcome developments that have forced the company onto the defensive and clouded its ability to raise the $\$ 1,000$ million it needs to complete clean-up operations by 1988 as planned.

GPU's financial predicament is made worse because NRC has not yet given the company permission to restart the undamaged Unit 1 reactor at Three Mile Island. Still at issue, in NRC's view, is whether the company management has the competence and integrity necessary for operating a nuclear reactor. NRC's doubts concern not only the implications of the Hartman allegations, but also allegations that the company broke NRC regulations during the clean-up operation and failed to submit two consultants' reports promptly to NRC.

In September, an interim report released by NRC upheld allegations that many NRC rules and procedures had been violated during the clean-up operation at Unit 2 (see Nature 6 October, p.461). The commission is also investigating charges that employees who complained about the rulebreaking were later intimidated and victimized. In June, NRC commissioner Victor Gilinsky issued a scathing memorandum outlining allegations of mismanagement at the company and warning that he would not approve a restart at Unit 1 until GPU's top managers were replaced.

GPU, meanwhile, has gone to extraordinary lengths to rebut those allegations. At the company's request, Admiral Hyman Rickover, former head of nuclear propulsion for the US Navy, is making an independent appraisal of the company's management abilities. The company has also produced a point-by-point response to the Gilinsky memorandum and has commissioned an independent assessment of the clean-up operation by Edwin Stier, former head of New Jersey's criminal justice division. Because the proceedings of grand jury inquiries are secret, the company has not yet been able to respond to last week's indictment.

Meanwhile, the clean-up operation at Three Mile Island is slowing down because GPU is short of funds. Entries to the containment building, once running at the rate of one a day, are down to one a week. According to a spokesman, some $\$ 400$ million of the total $\$ 1,000$ million set aside for clean-up has already been spent. The cost is being shared by GPU ratepayers, the utility industry, the federal government and the states of Pennsylvania and New Jersey. The utilities, however, have not yet stumped up their "voluntary contribution" of $\$ 150$ million. Peter David

\title{
Argentina to cut nuclear programme?
}

Vice-Admiral Carlos Castro Madero has announced his "irrevocable" decision to resign as head of Argentina's National Atomic Energy Commission (CNEA) - at the same time, giving strong hints that the new government of Raul Alfonsin may have to make major cutbacks in the existing nuclear energy programme.

Since the early 1950s, Argentina's nuclear power programme has been aimed at self-sufficiency in the production of fuel and heavy water as well as in the operation of power stations. In all negotiations with nuclear equipment suppliers, notably West Germany, Switzerland and the Soviet Union, CNEA has always tried to obtain technology which it could operate without foreign aid. Argentina has its own uranium deposits, and as late as 1980, CNEA officials were speaking confidently of fuel self-sufficiency by mid-1982, when the Córdoba enrichment plant was due to begin operation - to be followed by heavy water self-sufficiency in 1983 with the completion of the Arovito plant.

It is not clear whether these plants are yet in operation. Announcing his resignation on 4 November, Castro Madero told the press that the current nuclear plan up to the year 2000 included the construction of four power stations and "feasibility studies" of fuel and heavy water facilities, without making it clear whether these latter included Cordoba and Arovito. Implementing these plans, he admitted, would involve "obvious financial difficulties" to the new government.

The vice-admiral's departure from CNEA raises once again the possibility of Argentina's signing the Non-Proliferation Treaty. Castro Madero has on several occasions clashed with the "London Club" of nuclear suppliers over their "negative attitude" towards countries that do not yet have their own nuclear bomb. In 1980 , he publicly boasted that "with a little help" Argentina would be close to making her own nuclear bomb. Last April he commissioned a feasibility study on the production of nuclear-powered submarines for the Argentine navy.

Vera Rich 